\title{
Peroneal Artery
}

National Cancer Institute

\section{Source}

National Cancer Institute. Peroneal Artery. NCI Thesaurus. Code C33314.

An artery arising from the posterior tibial artery that supplies the muscles on the lateral side of the lower leg. 